\title{
AS SEIS PROPOSTAS PARA A SEGUNDA DÉCADA DA REVISTA
}

\author{
Angela Araujo da Silveira Espindola
}

Rafael SANTOS DE Oliveira

Editores

No ano passado, 2016, a Revista Eletrônica do Curso de Direito comemorou sua primeira década. Foram 32 números publicados, 369 artigos científicos inéditos produzidos por pesquisadores nacionais e estrangeiros. Foi no primeiro ano da segunda década que a Revista Eletrônica do Curso de Direito recebeu um dos seus maiores presentes: a conquista do extrato Qualis A1, ingressando no seleto grupo de pouco mais de $5 \%$ dos periódicos jurídicos brasileiros. Foi uma longa caminhada até aqui; motivo de grande orgulho para Editores, Conselho Editorial, Pareceristas e para todos aqueles que ajudaram a contar essa história.

A nova década da história da Revista Eletrônica do Curso de Direito, que inaugura com o grande desafio de manter a qualidade na sua gestão editorial e na sua produção científica, buscará inspiração nas seis propostas de Italo Calvino ${ }^{1}$ para o século XXI, quais sejam: “leveza”, “rapidez”, “exatidão”, “visibilidade”, “multiplicidade” e “consistência”. Estas seis especificidades são referidas por Calvino como valores literários para o novo milênio. É bem verdade que estas seis propostas foram apontadas 15 anos antes da chegada do novo milênio e que agora, passados mais de 15 anos do início do novo milênio devem ser enaltecidas como qualidades importantes não só para a literatura, mas para além da literatura. A Revista Eletrônica do Curso de Direito elege como pauta sua estas seis propostas por Calvino.

A leveza, em oposição à opacidade, ao peso e a leviandade, aposta na capacidade de olhar o mundo das mais diversas formas, na aceitação de várias perspectivas. A rapidez, em oposição à aceleração, aposta no ritmo e na agilidade. A exatidão, em contraste com a aleatoriedade, refere-se à meticulosidade nos detalhes, refere-se ao cuidado extremo. A visibilidade denota a capacidade imaginativa, aquela capacidade de pôr em foco visões de olhos

\footnotetext{
${ }^{1}$ CALVINO, Italo. Seis propostas para o próximo milênio: lições americanas. 3 ed. São Paulo: Companhia das Letras, 1990.
} 
fechados, de pensar por imagens visuais, transcendendo o texto escrito. A multiplicidade referese à rede de conexões entre fatos, entre pessoas e entre as coisas do mundo, refere-se à pluralidade do pensamento, enquanto possibilidade de entrar em contato com as diversas áreas do conhecimento. Por fim, a "consistência", proposta que Calvino não pode escrever por ter falecido antes, mas aqui nos apoiamos na teoria narrativista de José Calvo Gonzales ${ }^{2}$. A Revista Eletrônica do Curso de Direito, portanto, assume como desafio produzir uma consistência narrativa na produção do conhecimento jurídico.

Boa leitura!!

Os Editores.

${ }^{2}$ GONZÁLEZ, José Calvo. El discurso de los hechos. Editorial Tecnos: Madrid, 1993. GONZÁLEZ, José Calvo. O Direito Curvo. Porto Alegre: Ed. Livraria do Advogado, 2013. 